\title{
Foreign Direct Investment into Developing Asian Countries: The Role of Market Seeking, Resource Seeking and Efficiency Seeking Factors
}

\author{
Kavita Wadhwa \\ Faculty member and Senior Research fellow \\ \# F 009, F-Wing, Department of Finance, IBS Hyderabad \\ IFHE University \\ Shankerpally Road, Dontanapally, Hyderabad - 501203, India \\ Tel: 91-84-172-3660-5203Ｅ-mail: wadhwa.kavita@gmail.com \\ Sudhakara Reddy S (Corresponding author) \\ Faculty member and Senior Research fellow \\ \# F 007, F-Wing, Department of Finance, IBS Hyderabad \\ IFHE University \\ Shankerpally Road, Dontanapally, Hyderabad - 501203, India \\ Tel: 91-84-172-3660-6015 E-mail: sudhakarhere2003@gmail.com
}

Received: April 18, 2011

Accepted: June 15, 2011

Published: November 1, 2011

doi:10.5539/ijbm.v6n11p219

URL: http://dx.doi.org/10.5539/ijbm.v6n11p219

\begin{abstract}
According to eclectic theory of Dunning, FDI could be of four types: market seeking, resource seeking, efficiency seeking and strategic asset seeking. Market seeking factors of FDI such as market size, market growth, structure of domestic market, etc. aim at penetrating the local markets of host countries. While resource seeking investments are made in order to have access to cheap raw material, pool of labor, infrastructure, etc. New sources of competitiveness, economies of scope and specialization and low cost of production are some of the efficiency seeking factors of FDI. An attempt is made to study the impact of market seeking, efficiency seeking and resource seeking factors of host countries on FDI inflows of host countries by taking sample 10 Asian countries in the time period 1991 to 2008. Panel regression results show that all categories of FDI motivating factors have a significant impact on FDI inflows.
\end{abstract}

Keywords: Foreign Direct Investment, Dunning's framework, Market seeking, Efficiency seeking, Asian countries, Panel regression, GDP, Exports

\section{Introduction}

Foreign direct investment (FDI) has been among the fastest growing economic activities around the globe. The FDI flows across the globe has risen sharply, from an annual average of US\$142 billion during the period of 1985-1990 to over US\$385 billion in the year 1996 and then it made a record by reaching a record of US\$1.9 trillion in the year 2007 (UNCTAD, 2009). The developing countries are not an exception to this. These countries increase their annual share out of total world FDI from $15 \%$ in 1990 to $30 \%$ in 2006 and then to $37 \%$ in the year 2008 (UNCTAD, 2009). The increasing FDI flows to developing countries since 1990 indicates that multinational companies have considered these hose countries as the profitable investment destinations (Kokko, 2000). Also, for developing countries FDI represents an important source of finance.

FDI plays a very important role in enhancing the welfare of host country due to benefits related to new innovation, new technology, new managerial techniques, development of skills, increased capital, creation of job opportunities and improvement in the working condition of employees and development of industrial sector in the host country (Caves, 1974; Haddad and Harrison, 1993; Perez, 1997; and Markusen and Venables, 1999). From the above mentioned benefits, it is clear that why developing countries are keen in attracting FDI. Hence, it is important for these countries to find what motives outside investors to invest in these countries.

The most conclusive justification of FDI as to what motives outside investor to invest in other markets is given by Dunning (1980) in his eclectic theory of FDI. He explained the determinants of FDI in Ownership, Location and Internalization advantages i.e. OLI framework. He says that a country should have any of these three advantages to attract FDI. Firstly, the firms should possess ownership advantages which enable them to compete efficiently in the local market, example, firm's production process, firm's competitive advantage over domestic firms, and also include patents, copyrights, technical know-how and management skills. Secondly, the host countries should possess some locational advantages which encourage outside firms to serve local market directly rather than going for exports, example, lower production and transportation cost, favorable tax 
treatments, lower risks, access to protected markets. And finally, the firms should have sufficient incentives to serve foreign firms through internal networks, example, lower transaction costs, minimum technology imitation, effective management and good quality control. Dunning (1988) states that these OLI advantages can vary depending on whether the countries are less developed or fully developed, big or small, whether industries are labor intensive or capital intensive, whether markets are emerging or mature, competitive or monopolistic.

There are four types of FDI derived from OLI theory of Dunning. These are market seeking FDI, resource seeking FDI, efficiency seeking FDI and strategic asset seeking FDI. The market-seeking FDI aims at penetrating the local markets of host countries and is usually connected with: market size and per capita income, market growth, access to regional and global markets, consumer preferences and structure of domestic market. The resource-asset seeking FDI seek and secure natural resources, for example, raw materials, lower unit labor cost of unskilled labor force and the pool of skilled labor, physical infrastructure (ports, roads, power, and telecommunication), and the level of technology. The efficiency-seeking FDI is motivated by creating new sources of competitiveness for firms and it goes where the costs of production are lower. And last, strategic asset seeking FDI aims advancing company's global or regional strategy into foreign networks of created assets like technology, organizational abilities and markets (Faeth, 2009).

So, an attempt is made to study the impact of market seeking, efficiency seeking and resource seeking factors of host countries on FDI inflows of host countries by taking sample 10 Asian countries in the time period 1991 to 2008 using a panel data model. Many studies are done to examine the determinants of FDI but most of the previous studies have emphasized the impacts of macroeconomic variables on FDI as a whole but this study has examined the individual impact of market seeking, resource seeking and efficiency seeking factors derived from the OLI framework of Dunning on FDI inflows.

The paper is organized as follows: Section I provided the introduction and Section 2 presents review of literature and hypotheses development. Data and model specification is given in Section 3. Results are discussed in Section 4 and Section 5 concludes the paper.

\section{Review of Literature and Hypotheses Development}

With increased globalization over the last decades the phenomena of FDI has increased and has become very important for global business. According to the Hecksher-Ohlin model as countries differ in their factor endowments, it leads to the factor price differentials among the countries. Therefore, a relatively capital abundant country would either export the capital intensive good to the host country or move capital to foreign locations where there is a high return on capital and low return on labor until the equalization of factor price.

Kindleberge (1969) and Hymer (1976) introduced the concept of MNE, which are large firms with market power. The emphasis of both the authors was on the concept of monopolistic advantage to explain the phenomena of FDI. Foreign firms want to enjoy ownership advantages such as product differentiation arising from market imperfection, the expertise of the management, the existence of internal and external economies of scale to and government policy interference to reduce the disadvantages of entering foreign markets. The disadvantages of entering foreign markets are higher risk, information asymmetry, cultural difference, the legal system.

Buckley and Casson (1976) made important contribution to the theory of FDI when they introduced the concept of internalization. According to them, the market of intermediate goods is highly imperfect with information asymmetry, and contract enforcement and bargaining costs. The decision of a firm to internalize depends upon industry-specific factors such as type of product, the structure of market, the economies of scale, factors specific to a region such as differences due to distance and culture, factors specific to nations such as political and financial factors and factors specific to firm such as management skills. According to them, MNE's that were high on research and development activities were high on the factor of internalization. Caves (1971) emphasized on differentiation of products as monopolistic advantage. According to him, in an imperfect market, MNE's engaged in product differentiation and were induced in horizontal FDI. This is because FDI was preferred over export or licensing when knowledge was employed in differentiation of products.

Root and Ahmed (1978) examined 44 economic, social and policy variables to test FDI inflows in 41 developing countries. They found per capita GDP, export-import ratio, transport and communication ratio, the extent of urbanization as determinants of FDI. Milner and Pentecost (1996) did an empirical study on US FDI in the UK manufacturing industry. They took export-sales ratio as comparative advantage, which according to them can be proxied as an alternative to skill intensity or labor-intensity in the country. For market size they took as proxy the industrial production of the UK. For measuring industry competitiveness, they took export-import ratio. They did a cross-sectional regression of 48 industrial groupings. They found market size, competitive advantage and competitiveness as significant explanatory variables.

Campos and Kinoshita (2003) used panel data regression analysis to study 25 transition economies to study between the period 1990 and 1998.They found out for the set of countries that FDI is influenced by the size of market, the low cost of labor, and the availability of abundant natural resources. Apart from these variables, trade openness and lower restrictions to FDI inflows were also significant factors. Garibaldi (2001) did a dynamic panel regression of 26 transition economies between 1990 and 1999. He analyzed a large set of macroeconomic variables. They were market size, fiscal deficit, inflation and exchange rate regime, country risk, economic reforms, trade openness, availability of natural resources, barriers to investment and bureaucracy. All the variables had expected signs and were significant. 
The eclectic framework of Dunning (1980) is used as a basic framework in this paper which seeks to examine the impact of market seeking, resource seeking and efficiency seeking factors of host on FDI inflows of host countries. Applying this framework, the study identifies three market seeking factors, four resource seeking factors and one efficiency seeking factor in 10 developing countries. All the factors are hypothesized in the following section:

\subsection{Market seeking factors}

In this category, we have used three variables, which are gross domestic product (GDP) of host country, population growth of host country and exports of host country which are also the proxies for economic growth and market size. The general implication is that the countries with faster economic growth and larger market size attract more market oriented FDI.

\subsubsection{Gross Domestic Product}

It is said that the countries with faster economic growth attract more market oriented FDI. Grcic and Babic (2003) have used GDP of the host country as an indicator of absolute market size. Agarwal (1980) found that the size of host country markets to be the most popular motive for outside investor to invest in host country, especially when FDI flows to developing countries are considered. Various other authors have also used the same measure to proxy market seeking FDI such as has also used GDP in host countries as one of the traditional determinant of FDI and found a positive correlation between GDP and FDI. So, all this lead to our first hypothesis which is as follows:

H1a: There is a positive relationship between the GDP of host country and FDI inflows to host country.

\subsubsection{Population Growth}

Population is also one of the market seeking factors of FDI as it is considered as proxy for size of the country or size of the market. Again the authors like Schneider and Frey (1985), Wheeler and Mody (1992), Tsai (1994), Taylor (2000), Chakarbarti (2001) and Nunnenkamp (2002) have used population as proxy for market size. Nunnenkamp (2002) has found that the correlation between population and FDI is stronger than that of GDP and FDI. Botric and Skuflic (2005) have also used population as one of the market seeking factor and expected the relationship between population and FDI to be positive but found a negative relationship. With this, they concluded that market seeking factors are not the reason for the investors to invest in South East European Countries. Since the expected relationship is positive so it is hypothesized that:

H1b: There is a positive relationship between population growth of host country and FDI inflows to host country.

\subsubsection{Exports}

Dunning (1980) has categorized exports under market seeking factors. The relationship between exports and FDI is controversial. Dunning (1998) says that the relationship between trade and FDI is conditional on the motivation of the FDI in question. If the FDI is market-seeking then it can displace exports from the home to the host country whereas if the FDI is efficiency- seeking FDI of resource seeking it will increase the volume of trade (Gray, 1998; Kojima, 1978; Buckley, 1983). The proximity-concentration hypothesis suggests that higher transaction costs arising from higher trade barriers and higher transportation cost lead to horizontal cross border expansion of production and hence, encourage FDI. In this case, international trade is more or less a substitute of FDI or international investment (Krugman, 1983; Horstmann and Markusen, 1992; Brainard, 1997). Thus, relationship between exports and FDI is negative. On the other hand, according to factor-proportion hypothesis, factor price differences encourage firms to engage themselves in cross border vertical integration which results in complementary relationship between FDI and international trade (Helpman, 1984; Markusen, 1984; Helpman and Krugman, 1985; Ethier and Horn, 1990). Thus, relationship between exports and FDI is positive in this case. So, this leads to the following hypothesis:

H1c: There is a positive/negative relationship between exports of host country and FDI inflows to host country.

\subsection{Efficiency seeking factors}

In this category, we have used one variable that is inflation.

\subsubsection{Inflation}

Inflation rate, which is determinant of locational advantage, implies macroeconomic stability and potential risk for foreign investors. In addition to openness and external debt, Botric and Skuflic (2005) have used inflation as an efficiency seeking factor. High rate of inflation and volatile inflation is a clear sign of macroeconomic instability and also considered as an impediment to FDI Botric and Skuflic (2005). Various other researchers like Asiedu, 2003; and Dizdarevic and August, 2005 have also used inflation rate as proxy for macroeconomic instability. Stability in inflation rate attracts more FDI, so a negative relationship is expected between inflation rate and FDI inflow. Thus, we frame the following hypothesis with regard to inflation and FDI:

$\mathrm{H} 2$ : There is a negative relationship between the inflation of host country and FDI inflows host of country.

\subsection{Resource seeking factors}

In this category, we have used variables which are imports and infrastructure. Infrastructure is most important resource seeking FDI factor because good infrastructure enhances the productivity of investments and hence attracts more FDI (Wheeler and Moody, 1992; Loree and Guisinger, 1995; Morisset, 2000; and Asiedu, 2002). 
Under infrastructure, we have used two variables which are internet users, mobile cellular subscriptions and road paved.

\subsubsection{Imports}

According to Dunning (1980), imports are one of the resource seeking factors. Like exports, imports are also having controversial relationship with FDI. As Dunning (1998) has argued that the relationship between trade and FDI is based on the motivation of FDI so theoretically there exists either relationship (positive or negative) between imports and FDI. Imports and FDI will have substitute relationship if host country earlier used to import from the investing (home) country but now home country (motivated by lower trade barriers and lower transportation costs) has started producing the same goods in host country. In this case, the relationship between imports and FDI will be negative. Now, reverse is also true. The relationship between imports and FDI can be complementary if FDI is resource seeking. If investing country requires some kind of inputs or factors which are not available in host country and are imported then more production will lead to increase of imports of inputs. In this case, the relationship between imports and FDI will be positive (Alguacil and Orts, 2002). This leads to the following hypothesis:

H3a: There is positive/negative relationship between imports of host country and FDI inflow of host country.

2.3.2 Internet Users

Botric and Skuflic (2005) have used internet users as one of the proxies of infrastructure. Pazienza and Vecchione (2009) have also used internet users to find out the determinants of FDI and found a positive relationship between internet users and FDI whereas Palit and Nawani (2007) have used internet users and internet host among other parameters to calculate infrastructure index, i.e. infostate. On the basis of these studies, we have also taken internet users as one of the parameters of infrastructure and expect a positive relationship between internet users and FDI and hence the hypothesis is:

H3b: There is a positive relationship between the Internet users and FDI inflows to host country.

\subsubsection{Mobile Subscribers}

Asiedu (2003) has used telephones per 1000 people to measure infrastructure development and found a positive relationship between telephone lines and FDI. Botric and Skuflic (2005) have also used telephone lines to proxy infrastructure. We have used mobile subscribers as one of the proxies of infrastructure development. So, on the basis of previous studies, we frame the following hypothesis:

H3c: There is a positive relationship between the mobile subscriptions and FDI inflows to host country.

\subsubsection{Roads Paved}

Infrastructure includes host of other essential services also apart from internet users, telephone users like roads, air and sea ports etc. Dizdarevic and August (2005) have calculated index for infrastructure reform which is a composite score of five areas: electricity, railways, roads, telecommunication, water and waste water. They found a positive relation between infrastructure index and FDI. We have also used roads paved among our infrastructure proxies and hence, the following hypothesis is framed:

H3d: There is a positive relationship between roads paved of host country and FDI inflows of host country.

\section{Data and Model Specification}

The sample of the study is 10 developing countries which are Bangladesh, China, India, Indonesia, Iran, Malaysia, Pakistan, Thailand, Turkey and Vietnam. The time period of the study is from 1991 to 2008. As in most of the developing countries, the economic reforms were initiated in the first 90's and countries starting becoming global. Data for all the economic variables of all the countries is extracted from website of World Bank (available at www.worldbank.org).

The dependent variable used for the study is Annual FDI inflows. The independent variables used for the study are divided into three broad categories which based on motives of FDI inflows. The first category comes under Marketing seeking FDI factors. The variables considered in this category are Log (GDP), annual population growth, Exports of goods and services as a percentage of GDP. The next category belongs to Resource Seeking FDI factors which include Imports of goods and services as a percentage of GDP, Internet users per 100 people, Mobile cellular subscriptions per 100 people, Roads paved as a percentage of total roads. The third category is that of Efficiency seeking FDI factors proxied by annual inflation.

Panel regression model is used in the study as the data is a combination of times series and cross section. The following is the panel model which is estimated:

$$
\begin{gathered}
\text { LnFDI }_{\text {it }}=\alpha_{\mathrm{i}}+\beta 1 \text { LnGDP }_{\text {it }}+\beta 2 \text { PopGrowth }_{\text {it }}+\beta 3 \text { Exports }_{\text {it }}+\beta 4 \text { Imports }_{i t}+\beta 5 \text { Roadspaved }_{i t} \\
+\beta 6 \text { Internetusers }_{\text {it }}+\beta \text { Mobilesub }_{\text {it }}+\beta 8 \text { Inflation }_{\text {it }}+\Sigma \text { Di }
\end{gathered}
$$

where, $\mathrm{i}=1,2 \ldots \ldots .10$ (countries) $\mathrm{t}=1,2, \ldots \ldots \ldots . .18$ (years)

LnFDI is the natural log of annual FDI inflows in a country, which is our dependent variable.

\section{Empirical Results and Discussion}

As mentioned earlier, panel regression is used in the study. Data for 10 countries is collected for 18 years, thus making the number of observation equal to 180 . 
As the data also contains the time series, so stationarity is checked by using ADF (Augmented Dickey-Fuller) test. $<$ Table 1 $>$ shows the results of ADF test. From the table, it can be seen that we reject the null hypothesis that series has unit root. This indicates that all the variables are I (0), i.e. stationary.

\section{Insert Table 1 - here}

$<$ Table 2> shows the collinearity stastistics. One of the ways to check for multicollinearity is VIF (Variance Inflating Factor). It can be seen from the table that there is not an issue of multicollinearity in independent variables as VIF is less than 10 .

\section{Insert Table 2 - here}

$<$ Table $3>$ shows the regression results. As the data was panel in nature so regression is run with fixed as well as with time effects. Time effects did not show any significant results so the results are not reported. Regression without and with fixed are shown in the Table 3. In both the cases, the model is significant but R2 has increased significantly in the model having fixed effects. Also, sign of coefficients of some of the variables have also changed in fixed effects because of differences in the characteristics of different countries.

Taking market seeking factors in to consideration first, it is clear from $<$ Table $3>$ that GDP and exports are showing the significant and positive relationship with FDI which was also hypothesized whereas population growth is showing the reverse relationship as expected. But if we run the regression with fixed effects then out of three market seeking variables only GDP is showing the significant and positive relationship with FDI which means FDI of all the countries are not market seeking.

Among resource seeking variables, imports, internet users and mobile subscribers are showing the significant relationship whereas roads paved is showing the insignificant relationship. The relationship between imports and FDI is positive which means the developing countries import inputs for production done in their countries by investing countries. The relationship between mobile subscribers and FDI is same as expected that is positive whereas the relationship between internet users and FDI is found to be negative. Botric and Skuflic (2005) also found a significant and negative relationship between internet users and FDI and stated that this could be due to the fact that the developing countries have started using internet extensively only after 2000 .

However, even though the relationship is negative but this should be taken as opportunity for the future because domestic investments must be invested in the technology advanced areas. All the results for resource seeking factors are similar if we run regression with fixed effect which means there are no country differences with regard to resource seeking factors and we can conclude that FDI inflows in developing countries are more of resource seeking.

Efficiency seeking factor which is inflation is found significant and is showing a negative relationship with FDI as hypothesized. The result is same in case of fixed effects also.

\section{Conclusion}

The objective of the paper is to analyze the impact of market seeking, resource seeking factors and efficiency seeking of host countries on FDI inflows of host countries. Various variables under these three categories are analyzed. The study is carried on the developing countries which are Bangladesh, China, India, Indonesia, Iran, Malaysia, Pakistan, Thailand, Turkey and Vietnam. As the study is done on ten developing countries and also contains time series data, so we have used panel regression with fixed effects. Among market seeking factors, GDP and exports are showing the significant and positive relationship with FDI which was also hypothesized. But in case of regression with fixed effects, only GDP is showing the significant and positive relationship with FDI which means FDI of all the countries are not market seeking. As far as resource seeking variables are concerned, imports, internet users and mobile subscribers are showing the significant relationship. The relationship between imports and FDI is positive which means the developing countries import inputs for production done in their countries by investing countries. The relationship between mobile subscribers and FDI is same as expected that is positive whereas the relationship between internet users and FDI is found to be negative. Negative relationship between internet users and FDI could be due to the fact that the developing countries have started using internet extensively only after 2000. However, even though the relationship is negative but this should be taken as opportunity for the future because domestic investments must be invested in the technology advanced areas. The results indicate that there are no country differences with regard to resource seeking factors and we can conclude that FDI inflows in all developing countries are more of resource seeking. Lastly, inflation which is a measure of macroeconomic instability has a negative impact on FDI which also supports the literature.

\section{References}

Agarwal, J.P. (1980). Determinants of foreign direct investment: a survey. Weltwirtschaftliches Archiv, 106, 739-77. [Online] Available: http://ideas.repec.org/a/spr/weltar/v116y1980i4p739-773.html

Alguacil, M.T., and Orts, Vicente. (2002). Inward Foreign Direct Investment and Imports in Spain. [Online] Available: http://www.fedea.es/hojas/publicaciones.html

Botric and Skuflic. (2005). Main Determinants of Foreign Direct Investment in the South East European Countries. [Online] Available: http://www.euroframe.org/fileadmin/user_upload/ (June 3, 2005)

Brainard, S. (1997). An Empirical Assessment of the Proximity-Concentration Trade-Off between Multinational Sales and Trade. American Economic Review, 87(4), 520-544. EBSCOhost. 
Brainard, S. L. (1993a). An empirical assessment of the factor proportions explanation of multinationals sales. [Online] Available: www.nber.org/papers/w4583

Buckley, P. J. (1983). Macroeconomic versus international business approach to direct foreign investment: a comment on Kojima's approach. Hitotsubashi Journal of Economics, 24, 95-100. [Online] Available: http://hermes-ir.lib.hit-u.ac.jp/rs/bitstream/10086/7932/1/HJeco0230100010.pdf

Buckley, P.J., and Casson, M. (1976). The Future of the Multinational Enterprise ( $1^{\text {st }}$ ed.). London: Macmillan, (Chapter 2).

Campos, Nauro F., and Kinoshita, Yuko. (2003). Why Does FDI Go Where it Goes? New_Evidence from the Transition Economies, IMF Working Papers 03/228, International Monetary Fund. [Online] Available: www.imf.org/external/pubs/ft/wp/2003/wp03228.pdf

Caves, R. E. (1974). Multinational Firms, Competition, and Productivity in Host-Country Markets. Economica, 41(162), 176-193. Retrieved from EBSCOhost. http://dx.doi.org/10.2307/2553765

Chakrabarti, A. (2001). The Determinants of Foreign Direct Investments: Sensitivity Analyses of Cross-Country Regressions. Kyklos, 54(1), 89-113. EBSCOhost. http://dx.doi.org/10.1111/1467-6435.00142

Dizdarevic, Nela and August, Maja. (2005). FDI Performance and Determinants in South East European Countries: Evidence from Cross-Country Data, Paper presented in Sixth International Conference on Enterprise in Transition, Development Issues. [Online] Available: http://bib.irb.hr/prikazi-rad?\&lang=en\&rad=203502.

Dunning, J. H. (1980). Towards an Eclectic Theory of International Production: Some Empirical Tests. Journal of International Business Studies, 11(1), 9-31. EBSCOhost. http://dx.doi.org/10.1057/palgrave.jibs.8490593

Dunning, J. H. (1988). The Eclectic Paradigm of International Production: A Restatement and Some Possible Extensions. Journal of International Business Studies, 19(1), 1-31. EBSCOhost. http://dx.doi.org/10.1057/palgrave.jibs. 8490372

Faeth, I. (2009). Determinants of Foreign Direct Investment - A Tale of Nine Theoretical Models. Journal of Economic Surveys, 23(1), 165-196. http://dx.doi.org/10.1111/j.1467-6419.2008.00560.x

Gray, Peter H. (1998). International Trade and Foreign Direct Investment: The Interface, in John H. Dunning, ed. Globalization, Trade and Foreign Direct Investment (Oxford: Elsevier).

Grcic, Branko and Babic, Zoran. (2003). The Determinants of FDI: Evaluation of Transition Countries Attractiveness for Foreign Investors. Paper presented in Fifth International Conference on "Enterprise in Transition", Session 1.4 Macroeconomic Policy and Investment.

Haddad, M., and Harrison, A. (1993). Are there Positive Spillovers from Direct Foreign Investment? Journal of Developing Economics, 42, 51-74. http://dx.doi.org/10.1016/0304-3878(93)90072-U

Helpman, E. (1984). A Simple Theory of International Trade with Multinational Corporations. Journal of Political Economy, 92(3), 451. EBSCOhost. http://dx.doi.org/10.1086/261236

Horstmann, I. J., \& Markusen, J. R. (1992). Endogenous market structures in international trade (natura facit saltum). Journal of International Economics, 32(1/2), 109-129. EBSCOhost. http://dx.doi.org/10.1016/0022-1996(92)90038-L

Hymer, S. H. (1976). The International Operations of National Firms: A Study of Direct Investment. Cambridge, MA: MIT Press.

Kindleberger, C. P. (1969). American Business Abroad: Six Lectures on Foreign Direct Investment. New Haven, CT: Yale University Press.

Kojima, Kiyoshi. (1978). Direct Foreign Investment, A Japanese Model of Multinational Business Operations (New York: Praeger).

Kokko, Ari. (2002). Globalization and FDI Incentives. Paper presented at the Annual Bank Conference on Development Economics in Europe, Oslo.

Krugman, P. (1983). New Theories of Trade among Industrial Countries. American Economic Review, 73(2), 343. EBSCOhost.

Loree, D. W., \& Guisinger, S. E. (1995). Policy and Non-Policy Determinants of U.S. Equity Foreign Direct Investment. Journal of International Business Studies, 26(2), 281-299. EBSCOhost. http://dx.doi.org/10.1057/palgrave.jibs.8490174

Markusen, J. R. (1984). Multinationals, Multi-Plant Economies, and the Gains from Trade. Journal of International Economics, 16(3/4), 205-226. http://dx.doi.org/10.1016/S0022-1996(84)80001-X

Markusen, J. R., and Venables A. J. (1999). Foreign Direct Investment as a Catalyst for Industrial Development. European Economic Review, 43, 335-356. http://dx.doi.org/10.1016/S0014-2921(98)00048-8

Milner, C., \& Pentecost, E. (1996). Locational advantage and US foreign direct investment in UK manufacturing. Applied Economics, 28(5), 605. EBSCOhost. http://dx.doi.org/10.1080/00036849600000040

Nunnenkamp, P. (2002). Determinants of FDI in Developing Countries: Has Globalization Changed the Rules of Game? Kiel Working paper No. 1122, Keil Institute of World Economics, Germany. [Online] Available: http://www.ifw-members.ifw-kiel.de/publications/de... the-game/kap1122.pdf 
Palit, Amitendu and Nawani, Shounkie. (2007). Technological Capability as a Determinant of FDI Inflows: Evidence from Developing Asia and India. Working paper No. 193, Indian Council for Research on International Economic Relations. [Online] Available: http://www.icrier.org/pdf/Working_Paper_193.pdf

Pazienza, Pasquale and Vecchione, Vincenzo. (2009). Preliminary Investigation of the Determinants of FDI Distribution in Italy. Journal of Business Economics and Management, 10, 99-107. http://dx.doi.org/10.3846/1611-1699.2009.10.99-107

Perez, T. (1997). Multinational Enterprises and Technological Spillovers: An Evolutionary Model. Journal of Evolutionary Economics, 7(2), 169. EBSCOhost. http://dx.doi.org/10.1007/s001910050040

Root, F. R., and Ahmed, A. A. (1978). The Influence of Policy Instruments on Manufacturing Direct Foreign Investment in Developing Countries. Journal of International Business Studies, 9(3), 81-93. EBSCOhost. http://dx.doi.org/10.1057/palgrave.jibs.8490670

Schneider, F., and Frey, B. S. (1985). Economic and political determinants of foreign direct investment. World Development, 13, 161-175. http://dx.doi.org/10.1016/0305-750X(85)90002-6

Taylor, C. T. (2000). The Impact of Host Country Government Policy on US Multinational Investment Decisions. World Economy, 23(5), 635. EBSCOhost. http://dx.doi.org/10.1111/1467-9701.00294

Tsai, Pan-Long. (1994). Determinants of Foreign Direct Investment and Its Impact on Economic Growth. Journal of Economic Development, 19, 137-163.

UNCTAD. (2009). World Investment Report 2009: Transnational Corporations, Agricultural Production and Development, UNCTAD. New York and Genebra.

Wheeler, D., and Mody, A. (1992). International investment location decisions: the case of US firms. Journal of International Economics, 33, 57-76. http://dx.doi.org/10.1016/0022-1996(92)90050-T

Table 1. Test for Stationarity (Augmented Dickey-Fuller Test)

\begin{tabular}{|l|c|c|}
\hline \multicolumn{1}{|c|}{ Variable } & t value & p value \\
\hline LnGDP & -4.7133 & 0.0001 \\
\hline PopGrowth & -3.4188 & 0.0115 \\
\hline Exports (at Ist level) & -12.8075 & 0 \\
\hline Imports & -3.5166 & 0.0086 \\
\hline Roadspaved & -3.5237 & 0.0084 \\
\hline Internetusers & -4.5533 & 0.0002 \\
\hline Mobilesub & -5.2866 & 0 \\
\hline Inflation & -3.6458 & 0.0058 \\
\hline
\end{tabular}

Table 2. Collinearity Statistics

\begin{tabular}{|l|c|c|}
\hline \multicolumn{1}{|c|}{ Variable } & Tolerance & VIF \\
\hline LnGDP & 0.562 & 1.778 \\
\hline PopGrowth & 0.618 & 1.618 \\
\hline Exports & 0.156 & 6.422 \\
\hline Imports & 0.201 & 4.965 \\
\hline Roadspaved & 0.72 & 1.389 \\
\hline Internetusers & 0.268 & 3.724 \\
\hline Mobilesub & 0.293 & 3.412 \\
\hline Inflation & 0.931 & 1.074 \\
\hline
\end{tabular}


Table 3. Regression Results: Dependent variable - Annual FDI

\begin{tabular}{|c|c|c|c|c|c|c|}
\hline \multirow{2}{*}{$\begin{array}{c}\text { Independent } \\
\text { Variables }\end{array}$} & \multicolumn{3}{|c|}{ Without Fixed Effect } & \multicolumn{3}{|c|}{ With Fixed Effects } \\
\hline & Coefficient & t value & p value & Coefficient & t value & p value \\
\hline Constant & -9.3039 & -2.2289 & 0.0271 & -0.4690 & -0.0402 & 0.9680 \\
\hline LnGDP & 1.1617 & 7.5953 & 0.0000 & 0.8270 & 1.8621 & 0.0644 \\
\hline PopGrowth & -0.3996 & -2.0298 & 0.0439 & -1.0243 & -1.4302 & 0.1546 \\
\hline Exports & 0.0168 & 1.8833 & 0.0614 & -0.0046 & -0.4467 & 0.6557 \\
\hline Imports & 0.0225 & 2.0214 & 0.0448 & 0.0086 & 1.8779 & 0.0622 \\
\hline Roadspaved & -0.0012 & -0.3400 & 0.7342 & -0.0018 & -0.6392 & 0.5236 \\
\hline Internetusers & -0.0486 & -3.5909 & 0.0004 & -0.0241 & -1.8880 & 0.0608 \\
\hline Mobilesub & 0.0193 & 2.4903 & 0.0137 & 0.0143 & 1.9921 & 0.0480 \\
\hline Inflation & -0.0102 & -2.3074 & 0.0222 & -0.0077 & -1.5934 & 0.1030 \\
\hline D1 & & & & 2.7298 & 2.4747 & 0.0144 \\
\hline D2 & & & & 1.6770 & 1.5537 & 0.1222 \\
\hline D3 & & & & 1.8649 & 3.0963 & 0.0023 \\
\hline D4 & & & & -0.8328 & -1.3459 & 0.1802 \\
\hline D5 & & & & 3.8733 & 3.3495 & 0.0010 \\
\hline D6 & & & & 2.7642 & 3.5902 & 0.0004 \\
\hline D7 & & & & 2.1078 & 3.9858 & 0.0001 \\
\hline D8 & & & & 1.7886 & 2.2185 & 0.0279 \\
\hline \multirow[t]{2}{*}{ D9 } & & & & 3.1374 & 4.6281 & 0.0000 \\
\hline & \multicolumn{2}{|c|}{$\begin{array}{l}\text { Number of observations } \\
\text { R-Square } \\
\text { Adjusted R-Square } \\
\text { F-statistic } \\
\text { Prob (F-statistic) }\end{array}$} & $\begin{array}{c}179 \\
0.5769 \\
0.5570 \\
28.9745 \\
0.0000\end{array}$ & \multicolumn{2}{|c|}{$\begin{array}{l}\text { Number of observations } \\
\text { R-Square } \\
\text { Adjusted R-Square } \\
\text { F-statistic } \\
\text { Prob (F-statistic) }\end{array}$} & $\begin{array}{c}179 \\
0.8064 \\
0.7860 \\
39.4495 \\
0.0000\end{array}$ \\
\hline
\end{tabular}

